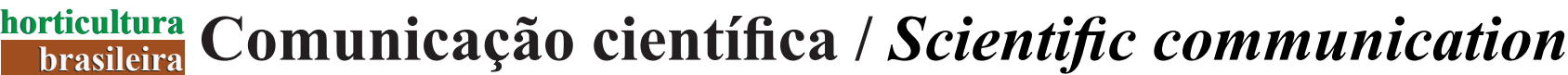

ARAÚJO PC; ALVES EU; URSULINO MM; ARAÚJO LR; SILVA RS. 2014. Different water volumes in the substrate and temperatures for germination of cabacinha seeds. Horticultura Brasileira 32: 367-370. DOI - http://dx.doi.org/10.1590/S0102-05362014000300021.

\section{Different water volumes in the substrate and temperatures for germination of cabacinha seeds}

\author{
Paulo C Araújo; Edna U Alves; Marina M Ursulino; Luciana R Araújo; Rosemere S Silva \\ UFPB-CCA, Depto. Fitotecnia e Ciências Ambientais, C. Postal 66, 58397-000 Areia-PB; pauloaraujo85@hotmail.com; ednaursulino@ \\ cca.ufpb.br; marina_matias88@yahoo.com.br; 1raraujo1@yahoo.com.br; rosyufpbio@hotmail.com
}

\begin{abstract}
Cabacinha (Luffa operculata) is a species that has been used empirically in folk medicine against sinusitis. The fruits have important pharmaceutical substances and studies related to its germination are not available, justifying the determination of the appropriate conditions that make possible the germination of its seeds. Thus, we evaluated the influence of different volumes of water in substrate and temperatures on germination and vigor of cabacinha. The treatments consisted of moistened substrate with water volumes equal to $2.0 ; 2.5 ; 3.0$ and 3.5 times its weight of the dry paper and the seeds were kept in germination regulated at constant temperatures of 25,30 and $35^{\circ} \mathrm{C}$ and $20-30^{\circ} \mathrm{C}$ alternating. The percentage and speed of germination, hypocotyl and roots of the plants were evaluated. The experimental design was completely randomized with treatments arranged in a $4 \times 4$ factorial (volumes of water $\mathrm{x}$ temperatures), in 4 replications of 25 seeds. The constant temperature of $30^{\circ} \mathrm{C}$ and the water volume of 2.0 times the weight of dry substrate is the best combination to lead the germination tests of cabacinha seeds.
\end{abstract}

Keywords: Luffa operculata, medicinal species, water availability, seeds analysis.

\section{RESUMO}

Diferentes volumes de água no substrato e temperaturas para a germinação de sementes de cabacinha

A cabacinha (Luffa operculata) é uma espécie que vem sendo utilizada empiricamente na medicina popular contra a sinusite. Seus frutos possuem substâncias farmacêuticas importantes e ainda são desconhecidos estudos relacionados à sua germinação; por isso justifica-se o conhecimento das condições apropriadas que viabilizem a germinação de suas sementes. Avaliou-se a influência de diferentes volumes de água no substrato e temperaturas na germinação e vigor de sementes da cabacinha. Os tratamentos consistiram do umedecimento do substrato com volumes de água equivalentes a 2,0;2,5; 3,0 e 3,5 vezes o peso do papel seco e as sementes foram mantidas em germinadores regulados nas temperaturas constantes de 25, 30 e $35^{\circ} \mathrm{C}$ e alternada de $20-30^{\circ} \mathrm{C}$. Foram avaliados a porcentagem e velocidade de germinação, comprimento do hipocótilo e das raízes. O delineamento experimental foi inteiramente ao acaso, com os tratamentos distribuídos em esquema fatorial $4 \times 4$ (volumes de água $\mathrm{x}$ temperaturas), em 4 repetições de 25 sementes. A temperatura constante de $30^{\circ} \mathrm{C}$ e o volume de água de 2,0 vezes o peso do substrato seco é a melhor combinação para conduzir os testes de germinação em sementes de cabacinha.

Palavras-chave: Luffa operculata, espécie medicinal, disponibilidade hídrica, análise de sementes.

(Recebido para publicação em 24 de outubro de 2013; aceito em 5 de junho de 2014) (Received on October 24, 2013; accepted on June 5, 2014)

$\mathrm{C}$ abacinha (Luffa operculata) (Curcubitaceae) is a Brazilian native species (Lorenzi \& Matos, 2008) whose nuts are traditionally used for preparing medicinal formulations, for aspirating the aqueous infusion has long been used empirically for treating sinusitis (Adler, 1999). The species has also been used as a laxative agent, an abortifacient, for the treatment of laryngitis, fever, herpes disease, ascites, eye diseases, tumors, syphilis, jaundice, tinea and "hydrops". According to some studies, this plant also has diuretic properties, kinetics, mucolytic, sudorific, expectorant and anthelmintic (Vasquez et al., 1986;
Brock et al., 2003).

Knowing the appropriate conditions that allow the germination of a species is essential, mainly by the different responses that can occur under the influence of various factors such as dormancy, volume of water, light, temperature, oxygen and presence of pathogens (Brasil, 2009; Carvalho \& Nakagawa, 2012).

Among the factors that affect seed germination, water availability is one of the most important; as it is with the absorption of water by soaking that the germination process starts (Borges \& Rena, 1993). In tests conducted in the laboratory, the substrate should be moistened sufficiently to ensure the resumption of growth of the embryonic axis (Marcos-Filho, 2005).

In Regras para Análise de Sementes (Rules for Seed Analysis) (Brazil, 2009), the recommendations about substrate moisture are based on water volume ratio and the weight of the paper substrate, without hydration, with indication of water volumes from 2.0 to 2.5 and from 2.5 to 3.0 times the weight of the paper substrate.

The availability of water is essential to trigger the germination of seeds, as found in a study by Menezes et al. (1993) 
with seeds of Cucurbitaceae: cucumber (Cucumis sativus), melon (Cucumis melo) and watermelon (Citrullus vulgaris). In gherkin seed (Cucumis anguria), substrates were moistened with water volumes equivalent to 1.0 ; $1.5 ; 2.0 ; 2.5$ and 3.0 times the weight of the dry substrate (Gentil \& Torres, 2001).

The temperature is also an important factor which influences the biochemical reactions which regulate the necessary metabolism to start the germination process, acting on the percentage and velocity of the process (Carvalho \& Nakagawa, 2012). Thus, the behavior of the seeds varies depending on the temperature of germination, and no single optimum temperature for seeds of all species was found, but a range from $20-30^{\circ} \mathrm{C}$ was considered by Borges \& Rena (1993), as the most suitable for the germination of seeds of many tropical and subtropical species.

Considering the importance of temperature and water availability in the substrate for seed germination, we aimed to evaluate the influence of different volumes of water in the substrate and the temperatures in germination and vigor of cabacinha seeds.

\section{MATERIAL AND METHODS}

The experiment was carried out in a laboratory of seed analysis from the Universidade Federal da Paraíba, Areia, Paraíba state, Brazil, in the period MayJune 2012.

The cabacinha seeds were obtained from ripe and dried fruits characterized by dark brown color, harvested from different plants, located in Lagoa de Velhos, Rio Grande do Norte state. Subsequently, the fruits were taken to the laboratory, opened manually and their seeds removed.

The water volumes $(\mathrm{mL})$ used to moisturize the paper towel substrate (Germitest) were: $2.0 ; 2.5 ; 3.0$ and 3.5 times the dry mass, without further addition of water and the temperatures for the germination of the seeds were constant $25,30,35^{\circ} \mathrm{C}$ and alternating $20-30^{\circ} \mathrm{C}, 8$ hours/day photoperiod and 16 hours/day of dark, considering $8 \mathrm{~h}$ at $30^{\circ} \mathrm{C}$ and 16 hours at $20^{\circ} \mathrm{C}$, using daylight type fluorescent lamps $(4 \times 20$ were scarified with sandpaper $n^{\circ} 80$ in the distal region to the embryo and treated with fungicide Captan $^{\circledR}$, at a concentration of $240 \mathrm{~g} / 100 \mathrm{~kg}$ of seeds, and evaluated on the following parameters:

Germination - for each treatment, four replications with 25 seeds in rolls of paper towel, packed in transparent plastic bags with $0.04 \mathrm{~mm}$ thick, in order to prevent loss of water by evaporation, and maintained in germination chamber type BOD (Biochemical Oxygen Demand). Daily counts were carried out, at the same time, from the fourth (first count) to the eighth day after the test installation, according to the preliminary data, by computing the percentage of normal seedlings, that means, those who had issued the primary root and hypocotyls and were apparently healthy (Brasil, 2009) and, the germination speed index was calculated according to the formula:

$$
\text { IVG }=\frac{G_{1}}{N_{l}}+\frac{G_{2}}{N_{2}}+\ldots+\frac{G_{n}}{N_{n}}
$$

proposed by Maguire (1962).

Root length and hypocotyls - after the final count of germination test, the primary root and hypocotyls lengths, of normal seedlings of each treatment, were determined, with the aid of a ruler graduated in centimeters, and the results expressed in $\mathrm{cm} /$ seedling.

Experimental design and
W). Before running the tests, the seeds

statistical analysis - the experimental design was completely randomized, with treatments arranged in a $4 \times 4$ factorial scheme (volumes of water $\mathrm{x}$ temperatures), with four replications. The data obtained were subjected to analysis of variance and polynomial regression, the most significant model order $\left(\mathrm{R}^{2}\right)$ being selected, with possible results to be explained, employing the equation that best fits the data, using the software SISVAR for Windows version 4.6 (Ferreira, 2003).

\section{RESULTS AND DISCUSSION}

For alternating temperature (20-30 $\left.{ }^{\circ} \mathrm{C}\right)$, a quadratic response of germination of cabacinha was observed, with the increased volume of water in the substrate. The largest percentage of germination $(99 \%)$ was obtained when the water volume 2,3 times the mass of the dry paper was used, whereas for constant temperatures $(25,30$, and $35^{\circ} \mathrm{C}$ ), germination behaved linearly, being reduced as the amount of water in the substrate was increased (Figure 1). Similarly, the germination of gherkin seeds (Cucurbitaceae) (Gentil \& Torres, 2001) was favored in lower volumes of water used to moisturize the substrate, being assigned to the volumes from 1.0 to 2.5 times the weight of the substrate. Tanaka et al. (1991) emphasized that excess of moisture causes deficiency in

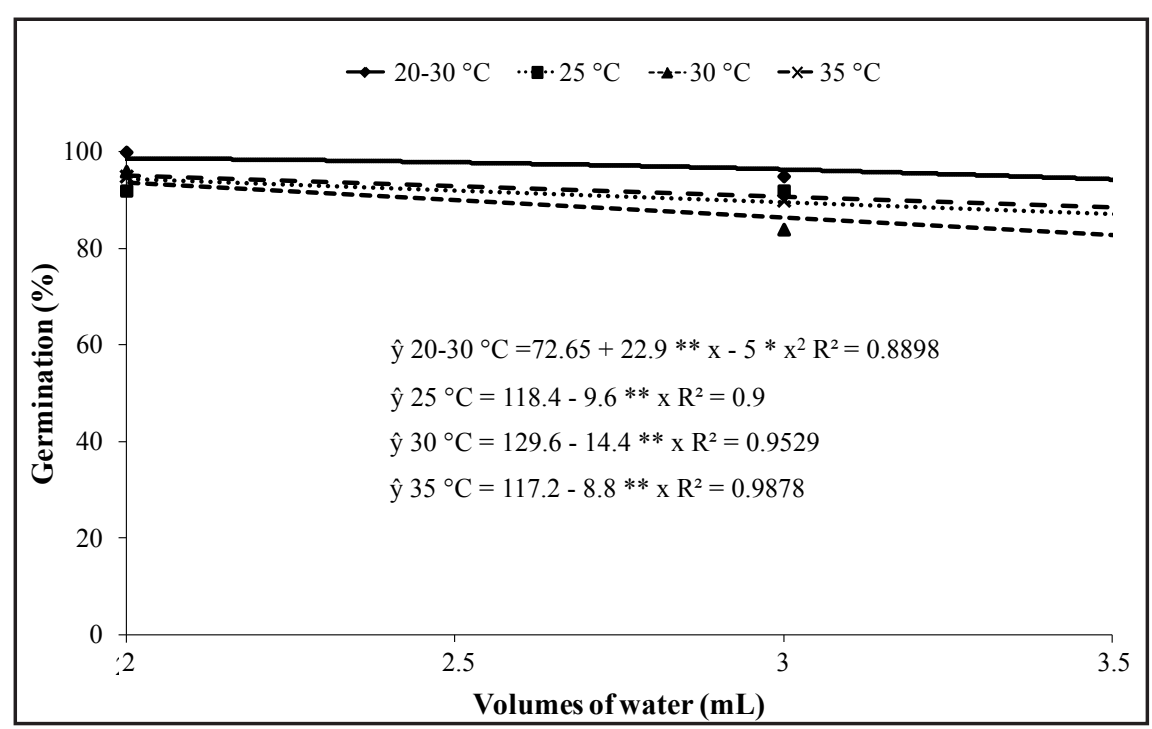

Figure 1. Germination (\%) of seeds of cabacinha subjected to different temperatures and volumes of water in the substrate [germinação (\%) de sementes de cabacinha submetidas a diferentes temperaturas e volumes de água no substrato]. Areia, UFPB, 2012. 


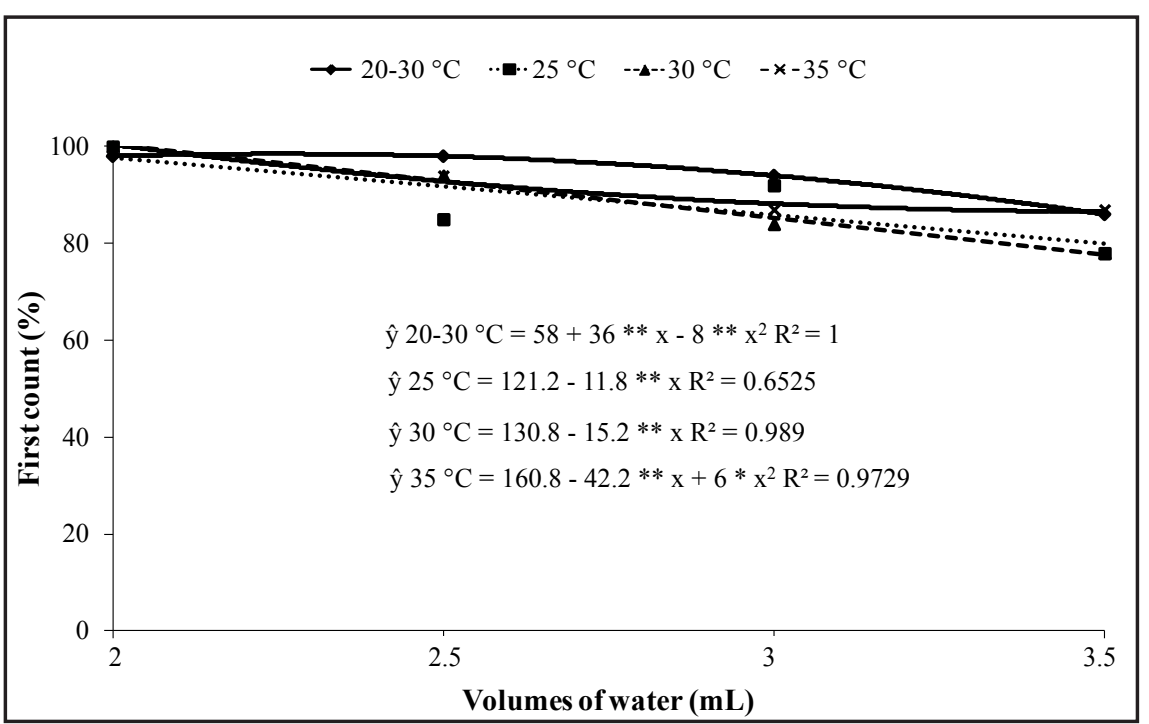

Figure 2. First count of seed germination of cabacinha subjected to different temperatures and volumes of water in the substrate (primeira contagem de germinação de sementes de cabacinha submetidas a diferentes temperaturas e volumes de água no substrato). Areia, UFPB, 2012.

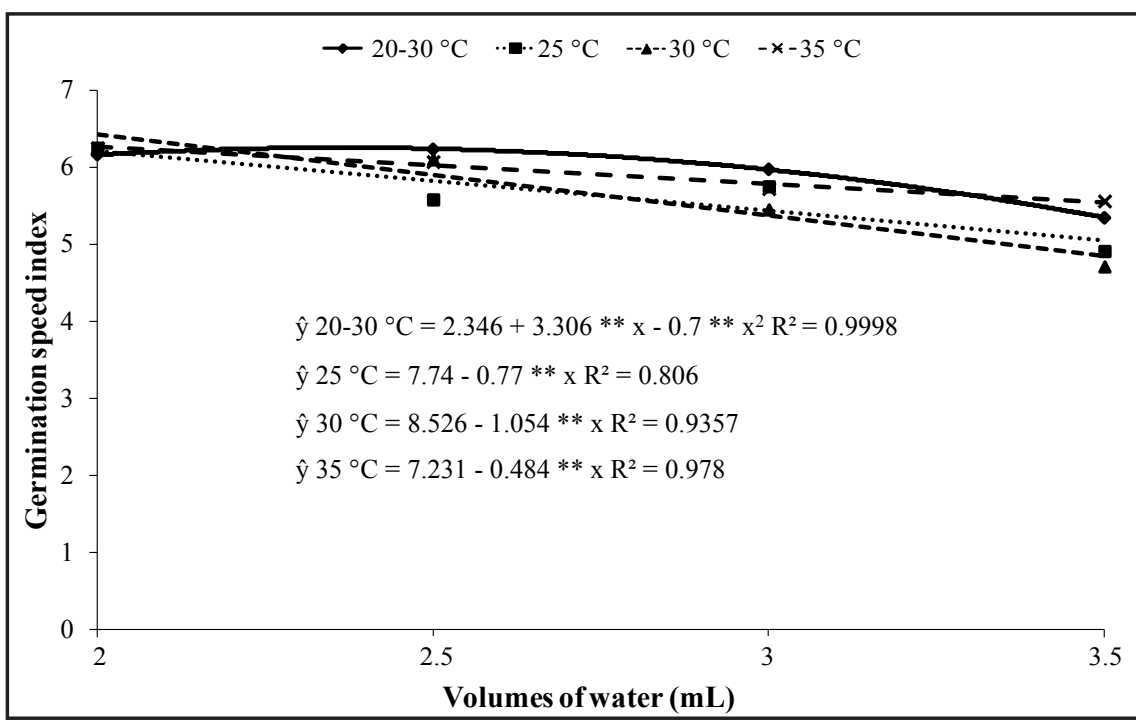

Figure 3. Germination speed index of cabacinha seeds subjected to different temperatures and volumes of water in the substrate (índice de velocidade de germinação de sementes de cabacinha submetidas a diferentes temperaturas e volumes de água no substrato). Areia, UFPB, 2013.

oxygen supply, an essential factor in the germination process.

The excess of moisture causes decreases in germination, as it hampers breathing and reduces all the resulting metabolic process, leading to a decrease in viability, besides contributing to the proliferation of pathogens (Pacheco et al., 2007). This may explain the low percentage of germination in larger quantities of water available in the substrate, during the germination tests conducted in this study. Similarly, the authors observed in other cucurbit seeds, species and easily found in the Northeast part of the country.

According to the data referred to vigor, determined by the first germination counting of cabacinha seeds (Figure 2), a quadratic response at temperatures of $20-30$ and $35^{\circ} \mathrm{C}$ was verified, with maximum vigor ( 99 and $87 \%$ of normal seedlings) when volumes of 2.3 and 3.5 were used, respectively; at temperatures of 25 and $30^{\circ} \mathrm{C}$, linear reduction of the vigor occurred as the volume of water was increased.

The temperature range between 20 and $30^{\circ} \mathrm{C}$ has been indicated as suitable for the germination of seeds of many tropical and subtropical species, whereas the maximum is from 35 to $40^{\circ} \mathrm{C}$ (Borges \& Rena, 1993). Although all the seeds of a species can germinate in a wide temperature range, the maximum germination percentage in the shortest period of time occurs in the optimal range (Bewley \& Black, 1994), as it was observed for seeds of cabacinha when using the optimal amount of water for moistening the substrate.

Regarding the germination speed index (GSI) a linear reduction at constant temperatures of 25,30 and $35^{\circ} \mathrm{C}$ was found; at alternating temperature of $20-30^{\circ} \mathrm{C}$, the highest rate $(6.25)$ was observed in the volume of water equivalent to 2.4 times the dry substrate (Figure 3). At adequate temperatures for germination, higher speed of water absorption occurs, with rapid softening of the seed coat and subsequent radicle protrusion, characterizing the ideal condition to trigger germination and seedling establishment (Carvalho \& Nakagawa, 2012).

The fact that germination occurs in different regimes of temperatures shows adaptation to natural thermal fluctuations of the environment, which gives the species a greater capacity to seedling establishment in the field, making them able to withstand the harsh environmental conditions (Guedes et al., 2010).

With respect to hypocotyls lengths of normal cabacinha seedlings (Figure 4), the authors verified linear adjustments for all data obtained, whereas at temperatures of $20-30,25$ and $30^{\circ} \mathrm{C}$, the hypocotyl length was adversely affected as the volume of water into 


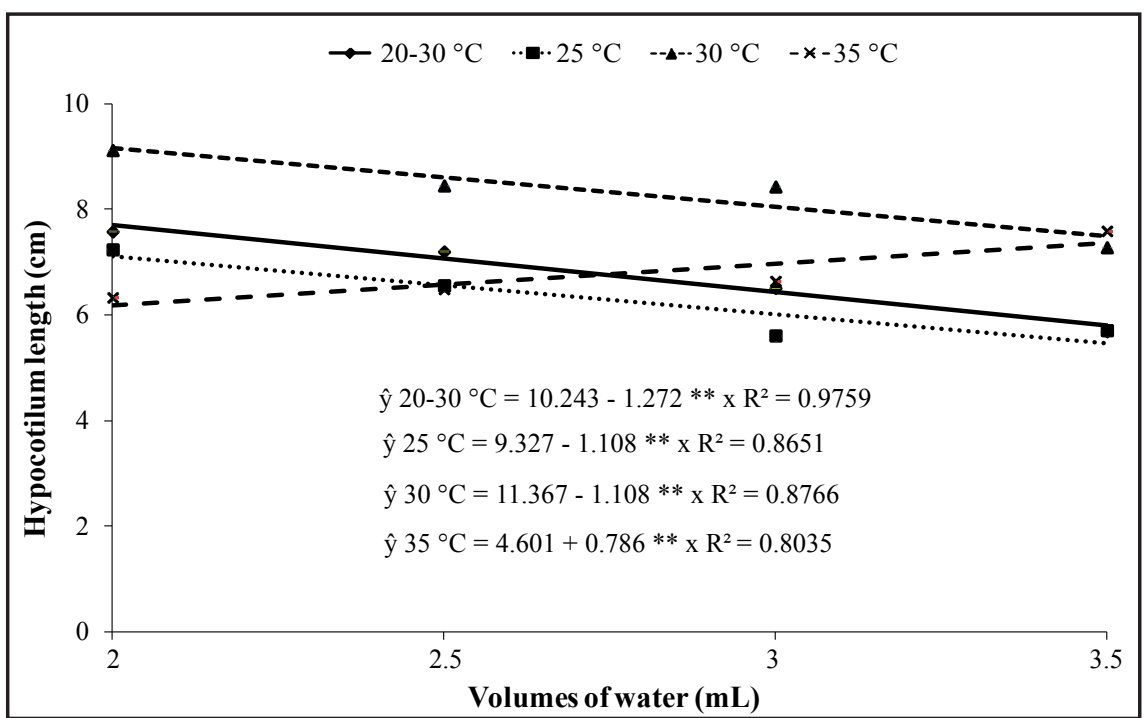

Figure 4. Hypocotilum length of seedlings arising from cabacinha seeds subjected to different temperatures and volumes of water in the substrate (comprimento do hipocótilo de plântulas oriundas de sementes de cabacinha submetidas a diferentes temperaturas e volumes de água no substrato). Areia, UFPB, 2012.

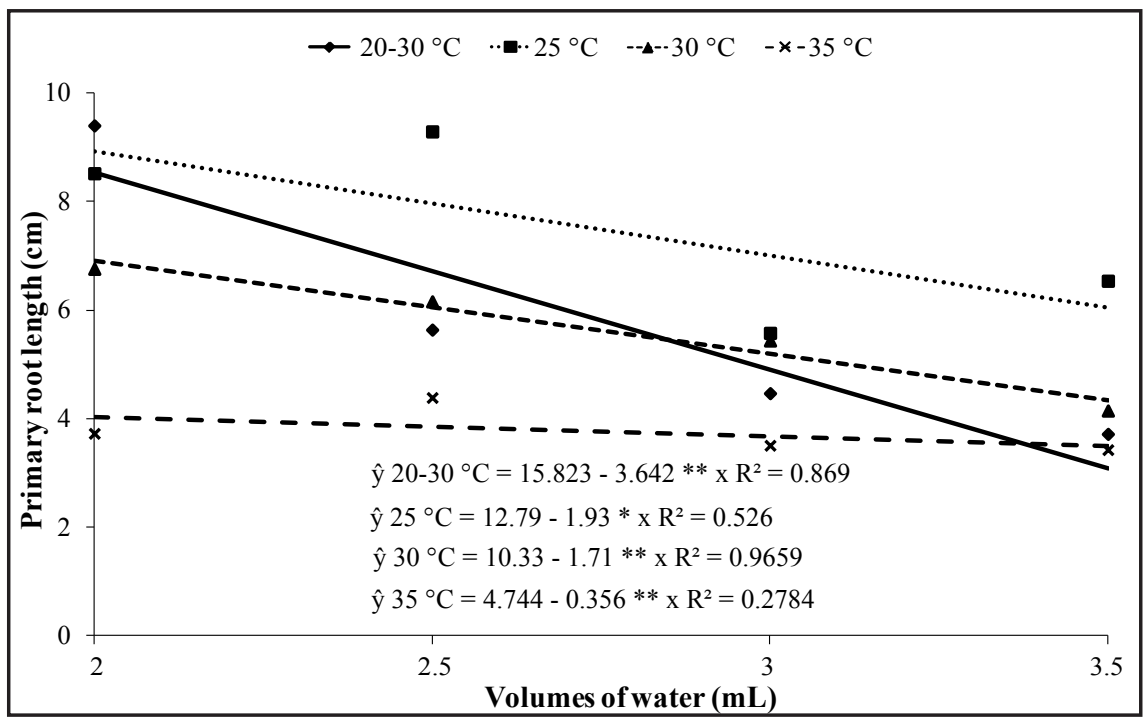

Figure 5. Primary root length of seedlings arising from cabacinha seeds subjected to different temperatures and volumes of water in the substrate (comprimento da raiz primária de plântulas oriundas de sementes de cabacinha submetidas a diferentes temperaturas e volumes de água no substrato). Areia, UFPB, 2012.

the substrate was increased, different from that observed at the temperature of $35^{\circ} \mathrm{C}$, for which the largest amount of water added into the substrate provided the greatest hypocotyl lengths. During the germination test, $1^{\circ} \mathrm{C}$ of temperature difference is likely to have negligible effect on the final germination percentage; however, this same difference will provide considerable effect on primary root length of the seedlings (Nakagawa, 1999).

For the primary root length of cabacinha seedlings (Figure 5), this study concluded that for all temperatures evaluated, a linear decrease was noticed as the volume of water into the substrate was increased, as well as for the hypocotyl length, the highest values being observed in lower amounts of water used to moisten the substrate.

Generally, we can affirm that the constant temperature of $30^{\circ} \mathrm{C}$ and the volume of water of 2.0 times the weight of dry substrate is the best combination to conduct tests of germination and vigor of seeds of cabacinha.

\section{REFERENCES}

ADLER M. 1999. Efficacy and safety of a fixedcombination homeopathic therapy for sinusitis. Pub Med 16: 103-111.

BEWLEY JD; BLACK M. 1994. Seeds: physiology of development and germination. New York: Plenum Press. 445p.

BORGES EEL; RENA AB. 1993. Germinação de sementes In: AGUIAR IB; PIÑARODRIGUES FCM; FIGLIOLIA MB (eds). Sementes florestais tropicais. Brasília: ABRATES. p. 83-135.

BRASIL. 2009. Ministério da Agricultura, Pecuária e Abastecimento. Regras para análise de sementes. Secretária de Defesa Agropecuária. Brasília: MAPA/ACS. 399p.

BROCK ACK; DUARTE MR; NAKASHIMA T. 2003. Estudo morfo-anatômico e abordagem fitoquímica de frutos e sementes de Luffa operculata, Cucurbitaceae. Visão Acadêmica 4: 31-37.

CARVALHO NM; NAKAGAWA J. 2012. Sementes: ciência, tecnologia e produção. 5.ed. Jaboticabal: FUNEP. 590p.

FERREIRA DF. 2003. SISVAR 4.6 Sistema de Análises Estatísticas. Lavras: UFLA.

GENTILDFO; TORRES SB. 2001. Umedecimento do substrato e germinação de sementes de maxixe (Cucumis anguria). Revista Brasileira de Sementes 23: 113-116.

GUEDES RS; ALVES EU; GONÇALVES EP; BRAGA JÚNIOR JM; VIANA JS; COLARES PNQ. 2010. Substratos e temperaturas para testes de germinação e vigor de sementes de Amburana cearensis (Allemão). Revista Árvore 34: 57-64.

LORENZI H; MATOS FJA. 2008. Plantas medicinais no Brasil: nativas e exóticas. 2. ed. Nova Odessa: Instituto Plantarum. 544p.

MAGUIRE JD. 1962. Speed of germination and in selection and evaluation for seedling emergence and vigor. Crop Science 2: 176-177.

MARCOS-FILHO J. 2005. Fisiologia de sementes de plantas cultivadas. Piracicaba: FEALQ. $495 \mathrm{p}$.

MENEZES NL; SILVEIRA TLD; STORCK L. 1993. Efeito do nível de umedecimento do substrato sobre a germinação de cucurbitáceas. Ciência Rural 23: 157-160.

NAKAGAWA J. 1999. Testes de vigor baseados no desempenho das plântulas. In: KRZYZANOWSKI FC; VIEIRA RD; FRANÇA NETO JB (eds). Vigor de sementes: conceitos e testes. Londrina: ABRATES. p. 1-24.

PACHECO MV; MATOS VP; FERREIRA LRC; FELICIANO ALP. 2007. Germinação de sementes de Apeiba tibourbou em função de diferentes substratos e temperaturas. Scientia Forestalis 73: 19-25.

TANAKA MAS; MARIANO MIA; LEÃO NVM. 1991. Influência da quantidade de água no substrato sobre a germinação de sementes de amendoim. Revista Brasileira de Sementes 13: 73-76.

VASQUES CAV; VASQUES NV; ARRAES LA; GELLER M. 1986. Revisão farmacognóstica da cabacinha (Luffa operculata). Folha Médica 93: 185-187. 